\title{
Experimental Study on the Valorization of Dredged Sediment from Reservoirs in Tunisia as Soil Amendment Regulating Metal Uptake by Crops
}

\author{
Slim Mtibaa, Najet Belkhamsa, Mitsuteru Irie, and Mohamed Ksibi
}

\begin{abstract}
Sediment deposited on the bottom of water reservoirs is known as clayey waste which causes a big problem in the sense of sustainability of surface water resources in Tunisia. Every year, the water storage capacities of reservoirs are decreased by more than $1 \%$. To cope with this situation, Tunisian government has adopted a national strategy for water and soil conservation since 1956. Nevertheless, the sedimentation rate is still high because this strategy is limited on the implementation of soil conservation measures such as terraces and hill lakes in some watersheds. Dredging, conventional but most effective countermeasure against sedimentation, is now required to recover the storage capacity of reservoirs. However, such countermeasure is not carried out in Tunisia because of its high cost. We have previously suggested to commercially valorize the sediment in order to cover partially the financial burden of the dredging activity. In this paper, we studied on the potential of the use of sediment as soil amendment. Sediment samples were extracted from different reservoirs in order to evaluate their ability to adsorb heavy metals and regulate the metals uptake by crops. Two methods have been carried out: a batch adsorption study and a semi field test. Results of this study show that the adsorption capacity is dependent on the mineralogical composition and the organic matter content of sediments. Metals are adsorbed on clay particles and carbonates containing in sediments, which decrease its mobility and accumulation in plants. The possibility of sediment valorization as soil amendment or adsorbent material is confirmed.
\end{abstract}

Index Terms-Valorization, dredging sediment, soil amendment, adsorption, metals uptake.

\section{INTRODUCTION}

Water is the foundation of life and still today all around the world, far too many people spend their entire day searching for it. Most experts consider that a 1000 cubic meters per capita per year is water shortage warning line. In case of Tunisia, the available volume of water per capita did not exceed 393 cubic meters in 2011, which is in the range of the scarcity of fresh water resource. To cope with the context of water shortage, Tunisia has adopted a rigorous water policy

Manuscript received October 12, 2015; revised December 29, 2015. This work was supported in part by funds from the SATREPS project for Valorization of Bio-ressources in Semi-arid and Arid land for Regional Development.

Slim Mtibaa, Najet Belkhamsa, and Mohamed Ksibi are with the Laboratory of Water, Energy and Environment, National Engineering School of Sfax, University of Sfax, Route Soukra km 3.5 Po. Box 1173, 3038 Sfax, Tunisia (e-mail: slim.mtibaa@th3pf.com, belkamssanajet@yahoo.fr, Mohamed.Ksibi@tunet.tn).

Mitsuteru Irie is with the Alliance for Research on North Africa, University of Tsukuba, 305-8577, 1-1-1 Tennodai, Tsukuba, Ibaraki, Japan (e-mail: irie.mitsuteru.fu@u.tsukuba.ac.jp). since 1960, based on two approaches: The first approach was based on the development of surface water resources with the valuable hydraulic infrastructures. Until now, about 30 reservoirs had been constructed for agricultural, industrial and domestic use. However, reservoirs storage capacity is decreasing year after year because of sedimentation. The capacity loss of the reservoirs caused by sedimentation in Tunisia is about $1.0 \%$ per year [1]. Solutions such as dredging and construction of flood water bypass have not been carried out because they are quite costly. Irie et al. [2] have previously proposed the exploitation and valorization of the sediment which can help shoulder the cost of dredging or other countermeasure to the sedimentation problem. The physical and chemical properties of sediment extracted from water storage reservoirs make it suitable for a variety of uses such as extracting fulvic acid for anti-allergy medicine [3], construction bricks [4] and soil amendment [5].

The second approach was based on the reuse of treated wastewater (TWW) for agricultural irrigation purposes. Indeed, even after conventional biological treatment, the TWW still contain substantial amounts of beneficial nutriments, yet also potentially hazardous elements such as metals. Thus, creating both opportunities and obstacles for agricultural production [6], [7]. Although TWW generally displays low concentrations of metals, the long-term use of this wastewater often results in the build-up of metal content in soils. The extent of metal content increase in irrigated soils depends on both the period and rate of wastewater application [8], where the potential exists that these contents could become bioavailable for crops [9]. Forecasting this accumulation of metals in agricultural soils irrigated by TWW constitutes a major environmental concerns given that the metal translocation into crops and ultimately into the food chain has already been recorded [10]. The persistent, biological concentration and diffusion of heavy metals have stimulated research efforts to develop the most appropriate technologies for the treatment of metal-contaminated water and soil. Chemical precipitation has been traditionally employed to remove heavy metals. However, metal removal via coagulation-precipitation is in many cases insufficient to meet strict regulatory requirements. Adsorption has been shown to be a feasible alternative method for removing metals. Active carbon is the most common adsorption method used in wastewater treatment all over the world [11]. However, its high cost causes restrictions in use.

The use of natural dredged sediment can be an effective solution for metals adsorption from either soil or water. The exploitation of natural sediment for the adsorption of metals has already been studied in former researchers from the point 
of view of physical property [12]. A several studies are reported in this area of research. Jeene [13] discussed the role of clay sized minerals in trace element sorption by soils and sediments. Fu and Allen [14] studied the adsorption of cadmium by oxic sediments using multisided binding model. Veli and Alyuz [15] concluded that natural clay can be used as an effective adsorbent for removing $\mathrm{Cu}^{2+}$ and $\mathrm{Zn}^{2+}$ from aqueous solutions. In this context, in a previous research, the authors have used the sediment extracted from a water reservoir as amendment of agricultural soils irrigated by TWW since 1989 in order to: 1 . Valorize the sediment which promote the sustainability of surface water resources and 2 . Ameliorate the soil quality by avoid problems of alkalinity, salinity and heavy metals accumulation. The use of dredged sediment for irrigated area by TWW was practically carried out in the field from the point of view metal adsorption characteristics of the sediment [5]. The plant uptake of metals was reduced due to the application of sediment. Significant differences were observed in heavy metals concentration in the plants seeded in the amended soil with sediment compared to control soil (without sediment). However, only the sediment sample extracted from Joumine reservoir with located in the north of Tunisia was tested. Also, the experiment was carried out at field conditions and with a constant rate of sediment (35 tons of sediment per hectare of soil) because of the difficulty of the management and the limited quantity of sediment. Supportive evidences for the adsorption effect of the sediment are required.

In this study, we aimed to evaluate the metals adsorption ability by natural sediment samples extracted from four different reservoirs.

\section{MATERIALS AND METHODS}

\section{A. Sediment Sampling}

Sediment samples were collected from the bed of four reservoirs located in the north of Tunisia by using an Ekman-berge bottom sampler $(15 \times 15 \times 15 \mathrm{~cm})$ (RIGO CO., LTD.). The location of the sampling points is shown as Fig. 1. The depths of the maximum water level of each reservoir at the sampling points were $25.5 \mathrm{~m}$ for Joumine reservoir, 22.3 $\mathrm{m}$ for Sejnene reservoir, $19.5 \mathrm{~m}$ for Mellegue reservoir and 9.8 for Masri reservoir. Two sub-samples of $2 \mathrm{~kg}$ dry weight were taken from each sampling point. Samples were packed into plastic bags in the field. In the laboratory, each tow samples were mixed, air dried, ground and passed through a $125 \mu \mathrm{m}$ aperture sieve before utilization as natural metal adsorbent. This fraction represents more than $95 \%$ of the sediments (granulometric analyses by Laser diffraction particle size analyzer, SALD3000, SHIMADZU, Japan).

\section{B. Physical and Chemical Analysis}

The mineralogical phases were identified by X-ray Diffraction (XRD) using an X-ray diffractometer Bruker (D8 advance). X-ray tube operating at $40 \mathrm{kV}$ and $40 \mathrm{~mA}, 0.6 \mathrm{~mm}$ fixed divergence slits, diffracted beam curved graphite monochromator $(\mathrm{Cu} \mathrm{K} \alpha+1$ radiation, $\lambda 1=1.540600 \AA$, $\lambda 2=1.544390 \AA$ ) and $0.1 \mathrm{~mm}$ fixed slit in front of the scintillation detector. The data were collected in the $2 \theta$ range $5-70^{\circ}$ with a step size of $0.02^{\circ}$ and a counting time of $2 \mathrm{~s} / \mathrm{step}$ $\mathrm{pH}$ and the Electrical Conductivity (EC) were determined by standard methods, the point of zero charge (pzc) was determined to find the surface charge of sediments using $0.1 \mathrm{M} \mathrm{KCl}$ solution at different $\mathrm{pH} \mathrm{[16].} \mathrm{Dissolved} \mathrm{total}$ carbon (DTC) in sediments was determined using a total organic carbon analyzer (aj-Analyzer multi N/C $2100 \mathrm{~S}$, Jena, Germany) after an extraction by $0.01 \mathrm{M} \mathrm{KNO}_{3}$ solution [17]. Exchangeable cations $\left(\mathrm{K}^{+}, \mathrm{Na}^{+}, \mathrm{Mg}^{2+}\right.$ and $\left.\mathrm{Ca}^{2+}\right)$ were analyzed using iCE 3500 Absorption Atomic Spectrophotometer (AAS) after extraction with 1M ammonium acetate according to the method NF X 31-108 described by AFNOR [18]. The Cation Exchage Capacity (CEC) was calculated by the following (1):

$$
\begin{gathered}
\mathrm{CEC}(\mathrm{mEq} / 100 \mathrm{~g})=\mathrm{Ca}^{2+}(\mathrm{ppm}) / 200+\mathrm{Mg}^{2+}(\mathrm{ppm}) / 120+\mathrm{K}^{+} \\
(\mathrm{ppm}) / 390+\left[9 \times\left(7.5-\mathrm{pH}_{\text {buffer }}\right)\right]
\end{gathered}
$$

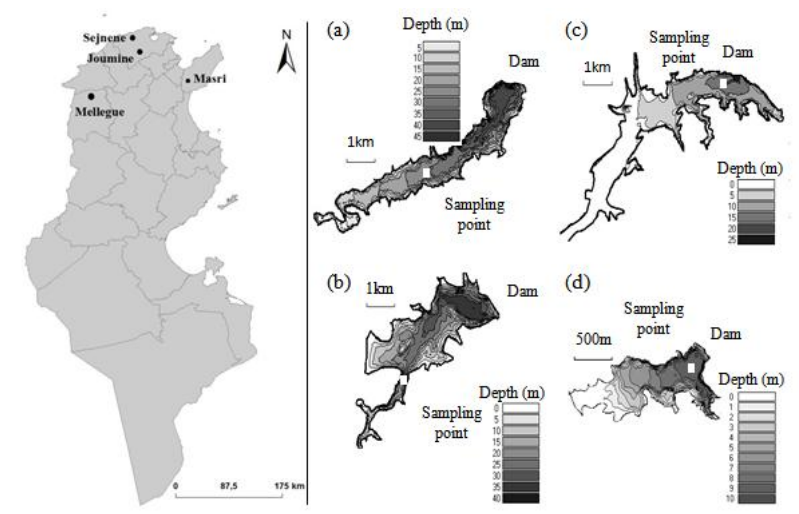

Fig. 1. Location of sampling point: (a) Joumine reservoir, (b) Sejnene reservoir, (c) Mellegue reservoir, (d) Masri reservoir.

\section{Batch Adsorption Study: Laboratory Test}

The selective nature of sediments was studied for $\mathrm{Cu}^{2+}$, $\mathrm{Pb}^{2+}$ and $\mathrm{Ni}^{2+}$. All sediment samples show the affinity for the metal ions as follow $\mathrm{Cu}^{2+}>\mathrm{Pb}^{2+}>\mathrm{Ni}^{2+}$. On the basis of this primary study, $\mathrm{Cu}^{2+}$ was selected for a detailed adsorption study [19]. Adsorption experiments were carried out in order to evaluate the potential adsorption of the different natural sediments. The influence of various experimental parameters such as contact time, mass of sediment and $\mathrm{pH}$ were studied. Adsorption experiments were carried out in a batch reactor. $250 \mathrm{mg} / \mathrm{L}$ of copper stock solution was prepared by dissolving $0.98 \mathrm{~g}$ of $\mathrm{CuSO}_{4} \cdot 5 \mathrm{H}_{2} \mathrm{O}$ in $1 \mathrm{~L}$ of distilled water. Batch kinetic experiments were performed by mixing $0.5 \mathrm{~g}$ of sediment to each flask with $50 \mathrm{ml}$ of copper solution of 250 $\mathrm{mg} / \mathrm{L}$ concentration and 7 as $\mathrm{pH} .200 \mathrm{rpm}$ stirring rate and $23^{\circ} \mathrm{C}$ temperature were applied in the shaker for all experiments. Samples were taken from the shaker at regular contact time intervals. Then, the sediment was separated by filtering. The concentration of copper remained in the solution was analyzed by iCE 3500 AAS. The equilibrium adsorption capacity $Q_{e}(\mathrm{mg} / \mathrm{g})$ was calculated as the following equation (2):

$$
Q_{e}=\frac{\left(C_{0}-C_{e}\right) V}{m}
$$

where $C_{0}$ is the initial copper concentration $(250 \mathrm{mg} / \mathrm{l}), C_{e}$ is the copper concentration at the equilibrium, $V$ is the volume of solution ( $\mathrm{L})$ and $\mathrm{m}$ is the mass of sediment $(0.5 \mathrm{~g})$.

In order to investigate the effect of $\mathrm{pH}$ on copper adsorption with sediment, aqueous copper solution of $50 \mathrm{~mL}$ 
in volume and $250 \mathrm{mg} / \mathrm{L}$ in concentration were used at $\mathrm{pH}$ ranging from 3.5 to 11.5 . $\mathrm{pH}$ adjustments were carried out using $0.1 \mathrm{~N} \mathrm{HCl}$ and $0.1 \mathrm{~N} \mathrm{NaOH}$ [19]. The agitation time was determined to be $1 \mathrm{~h}$ at $200 \mathrm{rpm}$ and the mass of sediment was kept constant $(0.5 \mathrm{~g} / 50 \mathrm{ml}$ of copper solution). The influence of the sediment mass was determined using a constant concentration of copper $(250 \mathrm{mg} / \mathrm{l})$ and different mass of sediment $(0.05 \mathrm{~g}$ to $0.5 \mathrm{~g})$.

\section{Statistical Analysis}

Data analysis was carried out using SPSS18 statistical package. Principal component analysis and Pearson correlation were used to analyze the multivariate relationships among sediment properties and adsorption capacities.

\section{E. Heavy Metals Uptake: Semi-field Test}

\section{1) Experimental design and preparation of experiments}

We proceeded to the soil amendment with sediment extracted from Joumine reservoir under homogeneous conditions. The variation of the Biological Accumulation Coefficient (BAC) and the Biological Concentration Factor $(\mathrm{BCF})$ as a function of three factors was studied. These factors are: the percentage of sediment in the soil $(2 \%, 6 \%$ and $10 \%)$, the soil salinity $(0.2,0.35$ and $0.5 \mathrm{~g} / \mathrm{kg})$ and heavy metal level (level1, level2 and level3). The different levels of salinity were used to study the effect of sediment on salinity. A Latin square design of experiments was built [20]. Hence, nine experiments are sufficient to identify the most influent factor mode (Table I).

\begin{tabular}{llll}
\multicolumn{4}{c}{ TABLE I: MATRIX OF EXPERIMENTS } \\
\hline \hline Sample & $\begin{array}{l}\text { Percentage } \\
\text { of sediment }\end{array}$ & $\begin{array}{l}\text { Soil salinity } \\
(\mathrm{g} / \mathrm{kg} \text { of soil })\end{array}$ & Metal level \\
\hline 1 & $2 \%$ & 0.2 & Level1 \\
2 & $2 \%$ & 0.35 & Level2 \\
3 & $2 \%$ & 0.5 & Level3 \\
4 & $6 \%$ & 0.2 & Level3 \\
5 & $6 \%$ & 0.35 & Level1 \\
6 & $6 \%$ & 0.5 & Level2 \\
7 & $10 \%$ & 0.2 & Level2 \\
8 & $10 \%$ & 0.35 & Level3 \\
9 & $10 \%$ & 0.5 & Level1 \\
\hline \hline
\end{tabular}

Natural soil irrigated by TWW from 1989 was used in these experiments. Zinc is highly accumulated in this soil [21]. For that reason, in this study we performed another experiment design using zinc besides copper. Table II shows the different concentration of metals used in this study.

\begin{tabular}{lll} 
& TABLE II: HEAVY METALS CONCENTRATION \\
\hline \hline Metal level & $\begin{array}{l}\text { Zinc concentration } \\
(\mathrm{mg} / \mathrm{kg})\end{array}$ & $\begin{array}{l}\text { Copper concentration } \\
(\mathrm{mg} / \mathrm{kg})\end{array}$ \\
\hline Level 1 & 20 & 5 \\
Level 2 & 30 & 6 \\
Level 3 & 40 & 7 \\
\hline \hline
\end{tabular}

Experiments or samples were prepared using agriculture soil. After dryness and homogenization, the soil was passed through a $2 \mathrm{~mm}$ aperture sieve. Metals were added to the soil using specific aqueous solutions of zinc and copper. After homogenization, the soil was analyzed to check the total concentration of metal. To obtain the different soil salinity levels, different concentration of $\mathrm{NaCl}$ were added to the soil, then, the soil was mixed manually. After preparation of the different soils, sediment was added according to the experiments matrix (Table I). Plants were being grown in pots using these prepared soils. Four replicate for each experiment were done. Twenty grains of Bromus ramosus were seeded in each pot at $1 \mathrm{~cm}$ from depth of soil surface and spry watered daily by deionized water. Growth test was realized under controlled conditions in a culture room for a period of 25 days, at a temperature of $22 \pm 3{ }^{\circ} \mathrm{C}$, a humidity of $70 \%$, and subjected to a light intensity of 4300 lux $\pm 10 \%$ according to a photoperiod of $16: 8$ (light : dark).

\section{2) Heavy metals analysis in soils and plants}

Soil samples were air-dried, ground and passed through a $2 \mathrm{~mm}$ aperture sieve, then, it were digested with Aqua Regia (3 $\mathrm{ml}$ hydrochloric acid $37 \%+1 \mathrm{ml}$ nitric acid 65\%) [22] Plant samples were gently washed with tap water to preserve roots and leaf, and then rinsed with deionized water. Oven dried plant tissues were ground into fine powder, then digested with tri acid mixture $\left(\mathrm{HNO}_{3}: \mathrm{H}_{2} \mathrm{SO}_{4}: \mathrm{HClO}_{4}: 5: 1: 1\right)$ till a transparent color appeared [23]. Heavy metals concentration in soils and plants were measured in the filtrate by using AAS. The BAC and the BCF were then calculated according to the following (3) and (4) [24].

$$
\begin{gathered}
B A C=\frac{\text { Concentration of metal in leafs }}{\text { Concentration of metal in soil }} \\
B C F=\frac{\text { Concentration of metal in roots }}{\text { Concentration of metal in soil }}
\end{gathered}
$$

\section{RESUlTS AND DISCUSSION}

\section{A. Physical and Chemical Characterization of Sediment}

Table III presents the general properties of the sediment samples. In general, sediments were found to be slightly alkaline $(\mathrm{pH} \approx 8)$. The DTC is about $0.5 \%$ of dried weight for Mellegue sediment and it is about $1 \%$ of dried weight for others 3 sediments. This content is probably coming from plants and animals' debris and microorganisms. Decaying plant material is the major source of sediment organic matter. Fig. 2 shows the X-ray diffraction pattern of sediment samples. The presence of large quantities of calcites, quartz $\left(\mathrm{SiO}_{2}\right)$, kaolinite, phyllosilictaes and smectite can be clearly distinguished. In sediments extracted form Joumine and Mellegue reservoirs, the amount of calcite is higher than quartz. Whereas, the reverse was found in the case of sediments extracted from Masri and Sejnene reservoirs. In particular, $\mathrm{CaCO}_{3}$ is found in large quantities $(63.83 \%)$ in Joumine and Mellegue. Therefore, it can be assumed that at least calcium may be considered as major elements in this analysis. X-ray results obtained for Masri and Sejnene revels that the amount of quartz reaches the value of $79 \%$. The others phases such us Smectite and Kaolinite are present in less quantity.

\begin{tabular}{llllll}
\multicolumn{2}{l}{ TABLE III: PHYSICAL AND CHEMICAL ANALYSIS OF SEDIMENT SAMPLES } \\
\hline \hline \multirow{2}{*}{ Reservoir } & $\begin{array}{l}\mathrm{pH} \\
{\left[\mathrm{H}_{2} \mathrm{O}\right]}\end{array}$ & $\begin{array}{l}\mathrm{EC} \\
(\mathrm{mS} / \mathrm{cm})\end{array}$ & $\begin{array}{l}\text { CES } \\
(\mathrm{mEq} / 100 \mathrm{~g})\end{array}$ & $\begin{array}{l}\text { DTC } \\
(\%)\end{array}$ & $\begin{array}{l}\text { Calcite } \\
(\%)\end{array}$ \\
\hline Joumine & 8.24 & 0.57 & 27.26 & 1.18 & 63.83 \\
Mellegue & 8.6 & 0.77 & 18.15 & 0.54 & 63.83 \\
Masri & 7.8 & 0.73 & 31.53 & 0.98 & 14.17 \\
Sejnene & 8.42 & 0.306 & 21.71 & 0.13 & 14.17 \\
\hline \hline
\end{tabular}



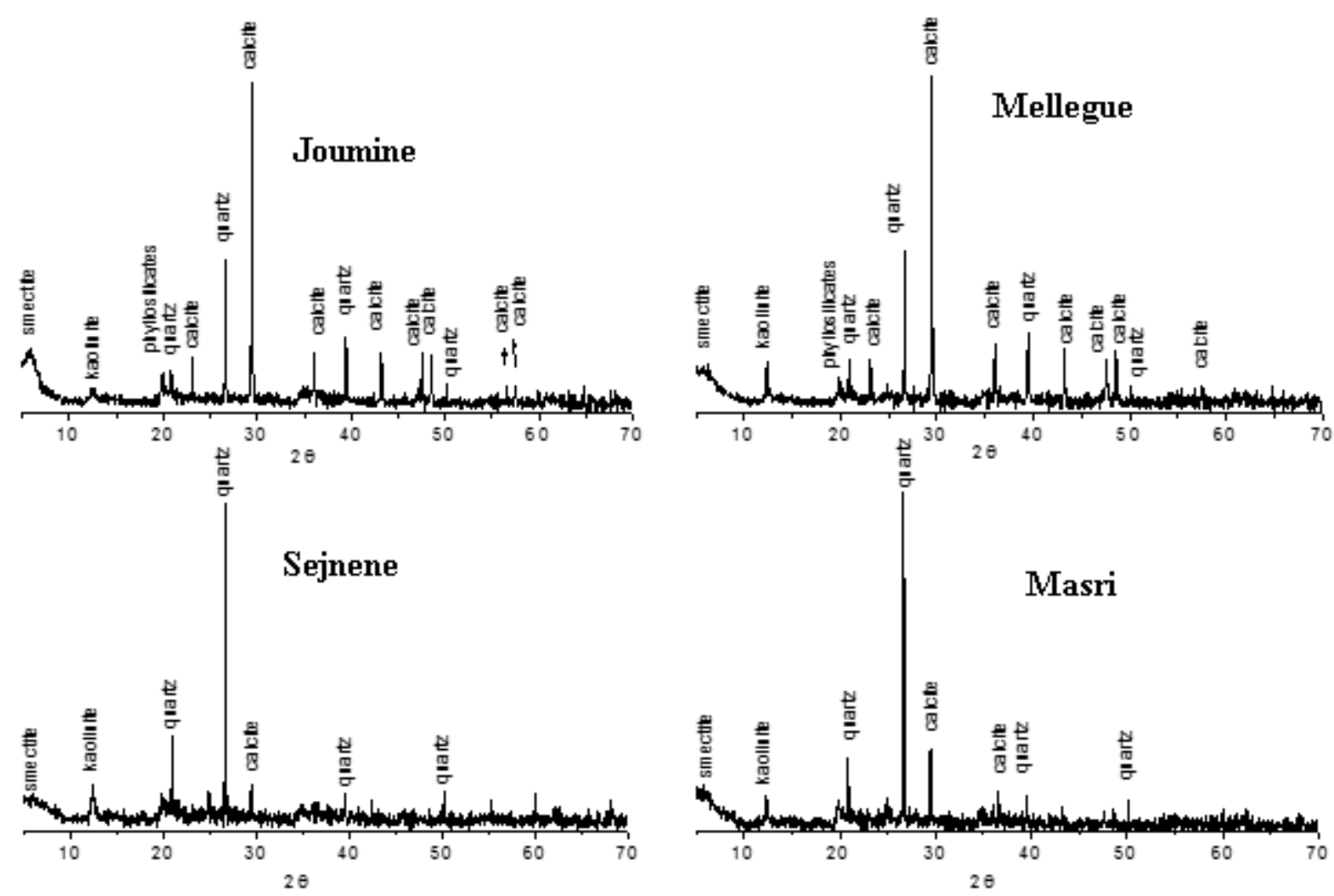

Fig. 2. X-ray diffraction pattern of the sediment samples.

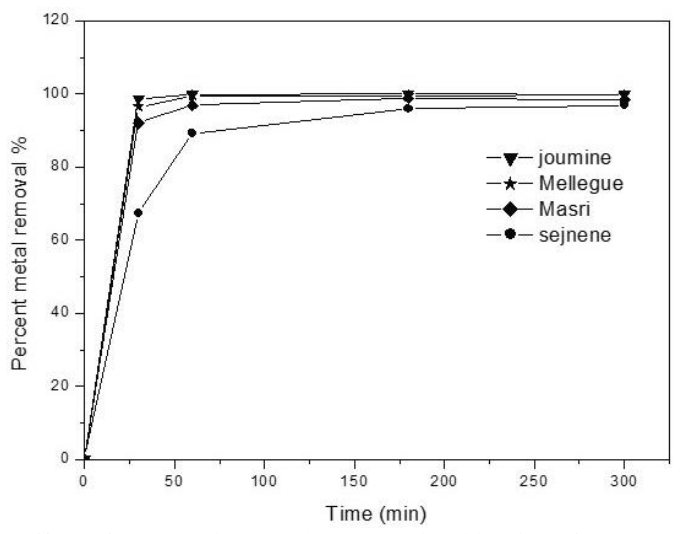

Fig. 3. Effect of contact time on the adsorption kinetics of copper: Initial concentration $=250 \mathrm{mg} / 1 ;$ Sediment mass $=0.5 \mathrm{~g} / 50 \mathrm{ml} ; \mathrm{pH}=7$.

\section{B. Batch Adsorption Study}

\section{1) Effect of contact time}

Fig. 3 shows the adsorption kinetics of copper at an initial copper concentration of $250 \mathrm{mg} / \mathrm{l}$. Results show that the equilibrium time required for the copper removal is $30 \mathrm{~min}$ for Joumine, Mellegue and Masri sediments and about 1 hour for Sejnene sediment which contains low quantity of calcite. It seems that the calcite is the most important element that affects the adsorption of copper on sediments. Thus, the copper ions are captured by calcite calcium carbonates during the adsorption experiments [25]. Besides, these results indicate that the sorption process can be considered very fast because of the largest amount of copper attached to sorbent within the first $30 \mathrm{~min}$ of adsorption. These observations are in agreement with the previous works of Hatij et al. [26] and Jain et al. [27]

\section{2) Effect of sediment dosage}

Fig. 4 shows the effect of sediment mass on the adsorption kinetics of copper. It can be concluded that the sediment mass has not an influence on the contact time necessary to reach equilibrium. This may be expected because, for a fixed initial metal concentration, the increase of the total sediments doses provides a greater surface area or adsorption sites, although the specific adsorption capacity decreases with the increasing of sediments doses $(0.05 \mathrm{~g} / 50 \mathrm{ml}$ to $0.5 \mathrm{~g} / 50 \mathrm{ml})$. The adsorption capacities are much improved by minimum effective substrate.
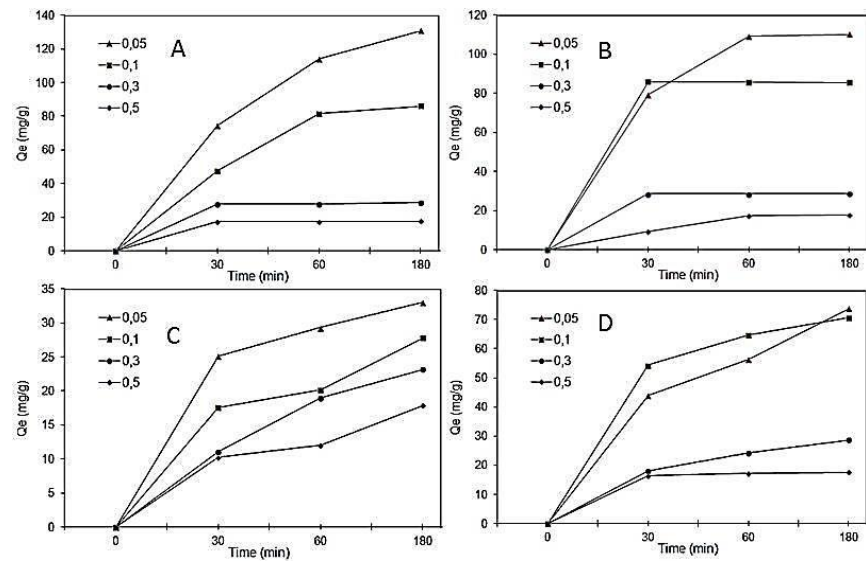

Fig. 4. Effect of sediment dosages on the adsorption kinetics of copper: (a) Joumine reservoir, (b) Mellegue reservoir, (c) Sejnene reservoir, (d) Masri reservoir.

Results of copper removal using different amount of sediments show that the adsorption capacity of copper decreases with the increase of sediment mass (Fig. 5). These results are in agreement with those reported by Dali Youcef et al. [12] and Sampedro et al. [28]. This is can be explained by the formation of aggregates at higher mass of sediments, which decreases the effective sorption area or a shortage of metal concentration in solution. Optimum sediment dosages 
that can be used in copper removal are $0.1 \mathrm{~g} / 50 \mathrm{ml}$ for Joumine and Mellegue sediments, $0.3 \mathrm{~g} / 50 \mathrm{ml}$ for Masri sediment and $0.5 \mathrm{~g} / 50 \mathrm{ml}$ for Sejnene sediment. The adsorption capacity of the used sediments is in the order: Joumine > Mellegue > Masri > Sejnene. Subsequent experiments were carried out by using only Joumine sediment because it has the highest adsorption capacity.

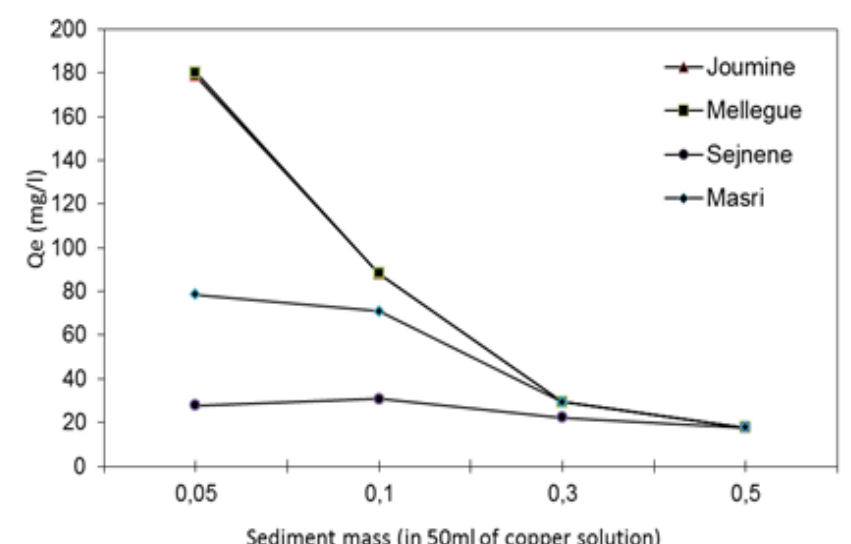

Fig. 5. Effect of sediment dosages on the adsorption kinetics of copper: Initial concentration $=250 \mathrm{mg} / \mathrm{l} ; \mathrm{pH}=7$; contact time $=1 \mathrm{~h}$.

\section{3) Effect of $p H$}

Results obtained using Joumine sediment as adsorbent are presented in Fig. 6 and show a lower metal adsorption at low $\mathrm{pH}$, which significantly increased with increasing $\mathrm{pH}$. A similar trend was reported for copper adsorption on activated carbon [29]. This may be explained with the formation of different species of copper:

$$
\begin{array}{lll}
\mathrm{Cu}^{2+}+\mathrm{H}_{2} \mathrm{O} & \Longleftrightarrow \mathrm{CuOH}^{+}+\mathrm{H}^{+} & p K_{1}=7.2-8.1 \\
\mathrm{Cu}^{2+}+2 \mathrm{H}_{2} \mathrm{O} \Longleftrightarrow \mathrm{Cu}(\mathrm{OH})^{+}+2 \mathrm{H}^{+} & p K_{1}=13.7-17.3 \\
2 \mathrm{Cu}^{2+}+2 \mathrm{H}_{2} \mathrm{O} \Longleftrightarrow \mathrm{Cu}(\mathrm{OH})_{2}{ }^{2+}+2 \mathrm{H}^{+} & p K_{1}=10.3-10.95
\end{array}
$$

The species of $\mathrm{Cu}^{2+}$ as an aquo-complex $\left[\mathrm{Cu}\left(\mathrm{H}_{2} \mathrm{O}\right)_{4}\right]^{2+}$ and $\mathrm{CuOH}^{+}$up to $7.0 \mathrm{pH}\left(<\mathrm{pK}_{1}\right.$ value $)$ are mainly involved in the adsorption process. The increase in adsorption of copper at higher $\mathrm{pH}$ may be attributed to the complex formation with $\mathrm{CuOH}^{+}$species accounting for electronic double layer on the charged oxide/hydroxide surface of the adsorbent [30]. This surface complexation approach to explain copper adsorption on various adsorbents was also investigated by Runkel et al. [31] and Wang et al. [32]. Although the adsorption of multinuclear species such as $\mathrm{Cu}_{2}(\mathrm{OH})_{2}{ }^{2+}$, based on spectroscopic evidence for its existence, was also considered by Subramaniam and Yiacoumi [33], whereas an explanation of copper adsorption under high surface coverage conditions, using triple layer/continuum models (TLM/CM), was ignored in the present work. This stems from the insignificant amount of such species when the $\mathrm{pH}$ was below 7.0 as reported by Archana et al. [34].

The maximum adsorption was found at $\mathrm{pH} 7.5$ for Joumine sediment. There was practically no adsorption on copper at very low $\mathrm{pH}$, but at a $\mathrm{pH}$ of 7.5 it was $50.2 \%$ from solutions containing $250 \mathrm{mg} / \mathrm{L}$ of copper. This behavior can be explained on the basis of surface charge of the adsorbent, which is indicated by the point of zero charge (pzc). The pzc value for Joumine sediment was found to be 9.4 as illustrated in the insert of Fig. 6. Thus, at lower $\mathrm{pH}$ the surface of the adsorbent would have a high positive charge density and uptake of the metal would be quite low because of electrostatic repulsion. With increasing $\mathrm{pH}$, the negative charge density on the surface of the adsorbent increases and, consequently, adsorption of $\mathrm{CuOH}^{+}$species takes place, thereby resulting in enhanced metal removal at $\mathrm{pH}$ 7.5. Thus, the mechanism of copper removal may be attributed to diffusion of $\mathrm{Cu}^{2+}$ from the bulk solution to the surface of the oxide/hydroxide component of the adsorbents, followed by hydrolysis, leading to the formation of the surface-metal complex SO-CuOH [33].

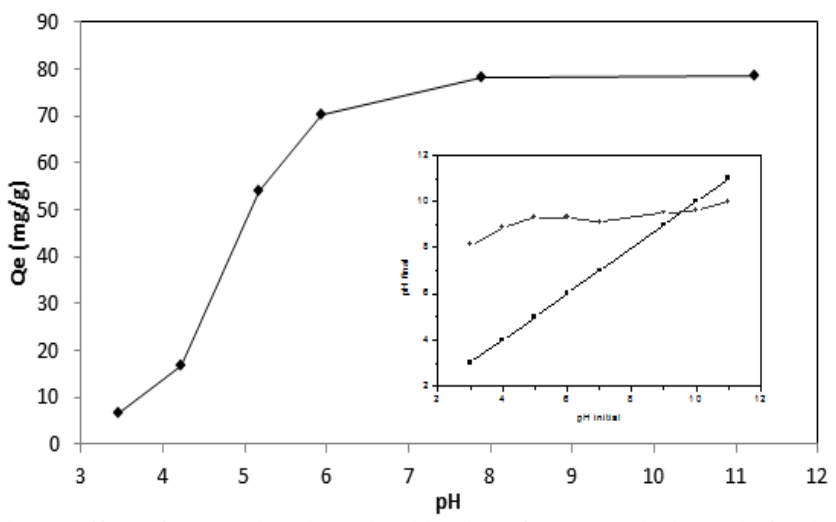

Fig. 6. Effect of $\mathrm{pH}$ on the adsorption kinetics of copper. The insert is for the determination of pzc.

\section{Statistical Analysis}

The statistical analysis was carried out only for the case of Joumine sediment because this later shows the higher adsorption capacity. The percentage of calcite in Joumine sediment was significantly high when compared to what was found in the other sediments (Table III). A significant positive correlation $(=0.979)$ was found between calcite percentage and the adsorption capacity $\left(\mathrm{Q}_{\mathrm{e}}\right)$. While, the correlations between the adsorption capacity and the percentage of quartz and the phyllo-silicates present in Joumine sediment are estimated to be 0.349 and -0.732 respectively (Table IV). This result confirms the high retention of copper by sediments extracted from Joumine and Mellegue, and the low retention of copper by sediments extracted from Masri and Sejnene. In fact, the percentage of calcite in Masri and Sejnene sediments is equal to $14.17 \%$ while that of quartz is about $79 \%$. These results clearly show that the percentage of calcite is a good factor for the retention of copper. Overall, the copper adsorption capacity $\left(\mathrm{Q}_{\mathrm{e}}\right)$ has a good affinity with calcite. This result can be verified by an analysis of the copper, which explains the capture of copper by calcite to lead to the incorporation of $\mathrm{Cu}$ (II) in the structure of calcite. This result is not surprising since the ionic radius of $\mathrm{Cu}^{2+}(0.077 \mathrm{~nm})$ is lower than $\mathrm{Ca}^{2+}(0.099 \mathrm{~nm})$ [35]-[37]. Some other basic chemical properties of the sediment were statistically correlated. The DTC and the $\mathrm{pH}$ were positively correlated with the adsorption capacity of copper as shown in the Table IV. DTC and CEC have inverse relationships with the regard of copper adsorption capacity.

In fact, DTC value has strong positive and significant correlation with $\mathrm{Q}_{\mathrm{e}}$ whereas CEC is negatively correlated with $\mathrm{Q}_{\mathrm{e}}$. Smith et al. [38] reported that sorption is also influenced by the CEC of clays, carbonate minerals, and organic matter present in soils and sediments. Thus, the retention of micronutrients and heavy metals can be 
increased with improving organic carbon status of soil. Sediment organic matter content is usually identified as the sediment constituent on metal retention [39].

TABLE IV: CORRELATION COEFFICIENTS BETWEEN PHYSIC-CHEMICAL PARAMETERS OF JOUMINE SEDIMENT AND ADSORPTION CAPACITY

\begin{tabular}{|c|c|c|c|c|c|c|c|c|c|}
\hline & $\mathrm{pH}$ & pzc & $\mathrm{EC}$ & DTC & CEC & $\mathrm{Q}_{\mathrm{e}}$ & Calcite & Quartz & Silicate \\
\hline $\mathrm{pH}$ & 1 & & & & & & & & \\
\hline $\mathrm{pzc}$ & -0.929 & 1 & & & & & & & \\
\hline $\mathrm{EC}$ & 0.189 & 0.189 & 1 & & & & & & \\
\hline DTC & $1.000 * *$ & -0.929 & 0.189 & 1 & & & & & \\
\hline CEC & -0.954 & $0.997 *$ & 0.115 & -0.954 & 1 & & & & \\
\hline $\mathrm{Q}_{\mathrm{e}}$ & 0.915 & $-0.999 *$ & -0.223 & 0.915 & $-0.994^{*}$ & 1 & & & \\
\hline Calcite & 0.978 & -0.986 & -0.021 & 0.978 & $-0.996^{*}$ & 0.979 & 1 & & \\
\hline Quartz & 0.697 & -0.381 & 0.836 & 0.697 & -0.450 & 0.349 & 0.532 & 1 & \\
\hline Silicate & -0.395 & 0.708 & 0.827 & -0.395 & 0.653 & -0.732 & -0.578 & 0.383 & 1 \\
\hline
\end{tabular}

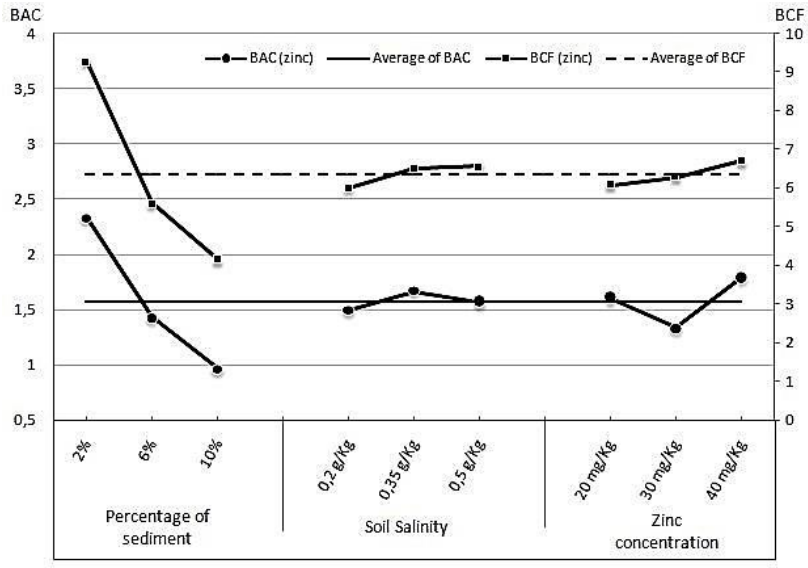

Fig. 7. Average effect if the percentage of sediment, soil salinity and zinc concentration of BAC and BCF of Zinc.

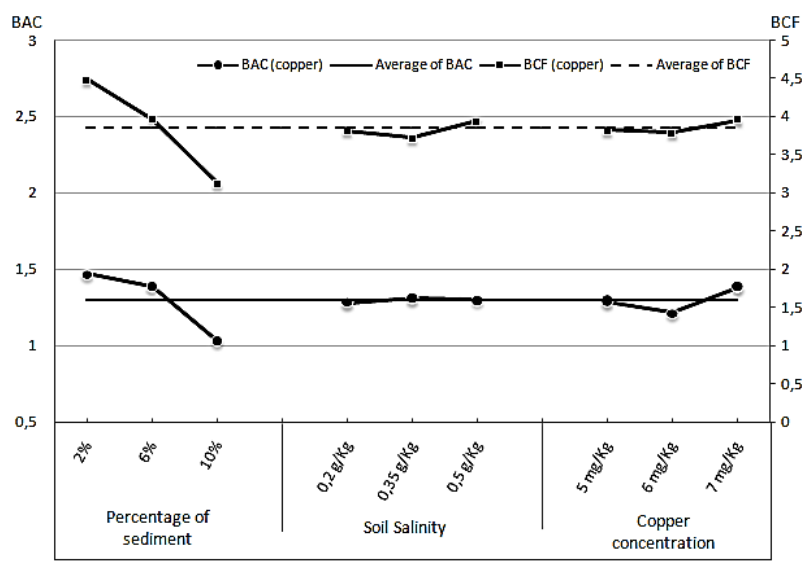

Fig. 8. Average effect if the percentage of sediment, soil salinity and zinc concentration of BAC and BCF of Copper.

\section{Zinc and Copper Uptake by Bromus Romosus}

Fig. 7 and Fig. 8 represent the average effect of the three factors mode on BAC and BCF for zinc and copper, respectively. In the experimental field, sediment concentration has a significant influence on BAC and BCF of Bromus ramosus for metals. In fact, when the amount of sediment increases in the soil, the bio-concentration of metals in root and the accumulation in leaves decrease. Sediment structure has been considered as very important parameter that affects the extent of the metals taken up by the plants [24]. In the soil, metals solubility was restricted due to it adsorption on clay particles and carbonates containing in the sediment [40]. On the other hand, organic matter containing in sediment could form chelates and complexes with metals which affect its bioavailability in soil. Indeed, the root exudates secreted by plants in the soil can change the mobility of metals, changing the $\mathrm{pH}$, ion concentration and redox conditions [41]-[43].

It is well known that, chloride salinity levels decrease the metals accumulation in plants [44] through osmotic stress affecting root function. In contrast we show in our study that salinity has no significant effect on BAC and BCF of metals. This is due to the low level of salinity used in our experiments and the physiological role of roots in the metal transfer. This is can be explained also by the application of sediment. Subsequent experiments should be carried out to highlight the effect of sediment on the salinity.

\section{CONCLUSIONS}

The present study investigated the possibility of the valorization of natural sediments as soil amendment regulating metals uptake by crops. Results of the batch adsorption experiments showed that the sediment extracted from Joumine reservoir has the highest adsorption capacity of metals due to the presence of the high content of calcite and organic matter. Adsorption capacities of the different sediments are in the order: Joumine > Mellegue > Masri > Sejnene. Semi field experiments showed that the BAC and the BCF of Bromus ramosus for zinc and copper decrease when the percentage of sediment increased in the soil. Sediment was found able to affect the solubility of metals and decrease its bio availability and mobility in the soil. However, soil salinity has no significant effect in our experiment.

The valorization of sediment as metal adsorbent can be a new conventional method for soils remediation. Subsequent study can be investigated for the production of ceramics porous filter, from sediments, which can be used for water treatment.

\section{ACKNOWLEDGMENT}

This research was supported in part by funds from the SATREPS project for Valorization of Bio-resources in Semiarid and Arid Land for Regional Development.

\section{REFERENCES}


[1] W. Remini and B. Remini, "La sédimentation dans les barrages de l'Afrique du Nord," Courrier du Savoir, vol. 4, pp. 65-69, 2003.

[2] M. Irie, A. Kawachi, J. Tarhouni, and A. Ghrabi, "Development of sedimentation and characteristics of sediment on the reservoir in Tunisia," Annual Journal of Hydro science and Hydrological Engineering, vol. 55, pp. 163-168, 2011.

[3] M. Irie, J. Han, A. Kawachi et al., "In vitro testing and commercialization potential of extracted fulvic acid from dredged sediment from arid region reservoirs," Journal of Waste and Biomass Valorization, vol. 5 pp. 273-281, 2014.

[4] M. Irie, K. Kashiwagi, K. Ujiie et al., "Feasibility of exploitation of the sediment in the reservoirs for the sustainability of surface water resource in Tunisia," Journal of Japanese Society and Civil Engineering Services, vol. G68, no. 6, pp. II41-II46, 2012.

[5] S. Mtibaa, M. Irie, O. Hentati et al., "Soil amendment by sediment from water storage reservoir as a restoration technique in secondary treated wastewater irrigated area at El Hajeb region (Sfax-Tunisia)," Journal of Arid Land Studies, vol. 22, no. 1, pp. 315-318, 2012.

[6] Y. Chen, C. Wang, and Z. Wang, "Residues and source identification of persistent organic pollutants in farmland soils irrigated by effluents from biological treatment plants," Environment International, vol. 31, pp. 778-783, 2005

[7] K. P. Singh, D. Mohan, S. Sinha, and R. Dalwani, "Impact assessment of treated/untreated wastewater toxicants discharged by sewage treatment plants on health, agricultural, and environmental quality in the wastewater disposal area," Chemosphere, vol. 55 pp. 227-255, 2004.

[8] R. K. Rattan, S. P. Datta, P. K. Chhonkar et al., "Long-term impact of irrigation with sewage effluents on heavy metal content in soils, crops and groundwater-a case study," Agriculture, Ecosystems and Environment, vol. 109, pp. 310-322, 2005.

[9] S. Toze, "Reuse of effluent water-benefits and risks," Agricultural Water Management, pp.147-159, 2006.

[10] M. Muchuweti, J. W. Birkett, E. Chinyanga et al., "Heavy metal content of vegetables irrigated with mixture of wastewater and sewage sludge in Zimbabwe: Implications for human health," Agriculture, Ecosystems and Environment, vol. 112, pp. 41-48, 2006.

[11] S. Veli and T. Öztürk, "Kinetic modeling of adsorption of reactive azo dye on powdered activated carbon and pumice," Fresenius Environmental Bulletin, vol. 14, pp. 212-218, 2005.

[12] N. Dali Youcef, B. Ouddan, and Z. Derriche, "Adsorption of zinc on natural sediment of Tafna river (Algeria)," Journal of Hazardous Materials, vol. A137, pp. 1263-1270, 2006.

[13] E. A. Jenne, "Trace element sorption by sediments and soils sites and processes," Marcel Dekker, New York, 1976, pp. 425-553.

[14] G. Fu, and H. E. Allen, "Cadmium adsorption by oxic sediments," Water Resources, vol. 26, pp. 225-233, 1992.

[15] S. Veli and B. Alyuz, "Adsorption of copper and zinc from aqueous solutions by using natural clay," Journal of Hazardous Materials, vol. 194, pp. 226-233, 2007.

[16] Y. C. Sharma, Uma, and S. N. Upadhyay, "Removal of a cationic dye from wastewaters by adsorption on activated carbon developed from coconut coir," Energy and Fuels, vol. 23, pp. 2983-2988, 2009.

[17] C. H. Stephan, F. Courchesne, W. H. Hendershot et al., "Speciation of zinc in contaminated soils," Environmental Pollution, vol. 155, pp. 208-216, 2008.

[18] AFNOR - NF X 31-108, "Soil quality, determination of ammonium acetate extractable $\mathrm{Ca}^{2+}, \mathrm{K}^{+}$and $\mathrm{Na}^{+}$cations, agitation method," 2002.

[19] R. Ahmad, R. Kumar, and S. Haseeb, "Adsorption of $\mathrm{Cu}^{2+}$ from aqueous solution onto iron oxide coated eggshell powder: Evaluation of equilibrium, isotherms, kinetics, and regeneration capacity," Arabian Journal of Chemistry, vol. 5, pp. 353-359, 2012.

[20] R. H. Lochner and J. E. Matar, Designing for Quality, an Introduction to the Best of Taguchi and Western Methods of Statistical Experimental Design, Productivity Press, 1990, Portland.

[21] N. Belaid, C. Neel, J. F. Lenain et al., "Assessment of metal accumulation in calcareous soil and forage crops subjected to long-term irrigation using treated wastewater: Case of El Hajeb-Sfax, Tunisia," Agriculture, Ecosystems and Environment, vol. 158, pp. 83-93, 2012.

[22] R. Pereira, S. C. Antunes, S. M. Marques, and F. Gonçalves, "Contribution for tier 1 of the ecological risk assessment of Cunha Baixa uranium mine (Central Portugal): I Soil chemical characterization," Science Total Environment, vol. 390, pp. 377-386, 2007.

[23] S. R. Allen, H. M. Grimshaw, and A. P. Rowland, "Chemical analysis. Methods in plant ecology,” Blackwell Scientific Publications, 1986 Boston.

[24] R. N. Malik, S. Z. Husain, and I. Nazir, "Heavy metal contamination and accumulation in soil and wild plant species from industrial area of
Islamabad, Pakistan," Pakistan Journal of Botany, vol. 42, no. 1, pp. 291-301

[25] Y. Kitano, N. Kanamori, and S. Yoshioka, "Adsorption of zinc and copper ions on calcite and aragonite and its influence on the transformation of aragonite to calcite," Geochemical Journal, vol. 10, pp. $175-179$

[26] V. Hatje, T. E. Payne, D. M. Hill et al., "Kinetics of trace metal uptake and release by particles in estuarine waters: effects of $\mathrm{pH}$, salinity, and particle loading," Environment International, vol. 29, pp. 619-629, 2003.

[27] C. K. Jain, D. C. Singhal, and M. K. Sharma, "Adsorption of zinc on bed sediment of River Hindon: adsorption models and kinetics," Journal of Hazardous Materials, vol. B114, pp. 231-239, 2004.

[28] M. A. Sampedro, A. Blanc, M. J. Llama, and J. L. Serra, "Adsorption of heavy metals to Phormidium Laminosum biomass," Biotechnology and Applied Biochemistry, vol. 22, pp. 355-366, 1995.

[29] S. A. Dastgheib and D. A. Rockstraw, "Pecan shell activated carbon: synthesis, characterization, and application for the removal of Copper from aqueous solution," Carbon, vol. 9, pp.1849-1855, 2001.

[30] J. O. Leckie and J. A. Davis, "Copper in the environment, part I (ecological cycling)," Wiley, 1979, New York.

[31] R. L. Runkel, B. A. Kimball, D. M. McKnight, and K. E. Bencala, "Reactive solute transport in streams: A surface complexation approach for trace metal sorption," Water Resources, vol. 35, no. 12 pp. 3829-3840, 1999.

[32] F. Y. Wang, J. S. Chen, and W. Forsling, "Modeling sorption of trace metals on natural sediments by surface complexation model," Environmental Science and Technology, vol. 31, no. 2, pp. 448-453 1997.

[33] K. Subramaniam and S. Yiacoumi, "Modelling kinetics of copper uptake by inorganic colloids under high surface coverage conditions," Colloid and Surface, vol. 191, pp.145-159, 2001.

[34] A. Archana, K. K. Sahu, and B. D. Pandey, "A comparative adsorption study of copper on various industrial solid wastes," Wiley. Inter Science, vol. 50, no. 10, pp. 2430-2438, 2004.

[35] L. Cheng, "Atomic scale study of ion incorporation at calcite surface using synchrotron X-Ray methods," Ph.D. dissertation, Northwestern Univ., 1998.

[36] T. Sharwan, B. Zuenbuel, O. Tunusoglu, and A. E. Eroglu, "AAS, XRPD, SEM/EDS and FTIR characterization of $\mathrm{Zn}^{2+}$ retention by calcite, calcite-kaolinite, and calcite-clinoptilolate minerals," Journal of Colloid and Interface Science, vol. 286, pp. 471-478, 2005.

[37] S. J. Freij, A. Godelitsas, and A. Putnis, "Crystal growth and dissolution process uses at the calcite-water interface in the presence of zinc ions," J. crystal. Growth, vol. 273, pp. 535-545, 2005.

[38] L. A. Smith, J. L. Means, A. Chen et al., Remedial Options for Metals-Contaminated Sites, Lewis Publishers, Boca Raton, 1995.

[39] C. W. Gray, R. G. McLaren, A. H. C. Roberts, and L. M. Condon, "Solubility, sorption and desorption of native and added cadmium in relation to properties of soils in New Zealand," European Journal of Soil Science, vol. 50, pp. 127-137, 1999.

[40] A. Karam, M. P. Cescas, and R. Ledoux, "Description de la sorption de 2n par les équations d'isothermes de Freundlich ou de Langmuir corrélations entre les constantes d'isothermes et les propriétés générales du sol (pH, argile)," Soil Science and Plant Analysis, vol. 14, no. 9 , pp. $785-801,1983$

[41] H. Marschner, Mineral Nutrition of Higher Plants, $2^{\text {nd }}$ Ed., Academie Press, London, 1995

[42] D. E. Salt, M. Blaylock, N. P. B. A. Kumar et al., "Phytoremediation A novel strategy for the removal of toxic metals from the environment using plants," Biotechnology, vol. 16, pp. 468-473, 1995.

[43] Y. Chaignon, F. Bedin, and P. Hinstnger, "Copper bioavailability and rhizosphere $\mathrm{pH}$ changes as affected by nitrogen supply for tomato and oilseed rape cropped on an acidic and a calcareous soil," Plant and Soil, vol. 243, pp. 219-228, 2002.

[44] A. Fritioff, L. Kautsky, and M. Greger, "Influence of temperature and salinity on heavy metal uptake by submersed plants," Environmental Pollution, vol. 133, pp. 265-274, 2005.

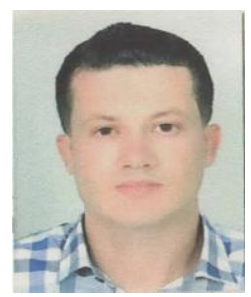

Slim Mtibaa is a $\mathrm{PhD}$ Student at the Graduate School of Life and Environmental Sciences, University of Tsukuba, Japan. 
Najet Belkhamsa is a PhD student working at the University of Sfax Faculty of Sciences with Prof. Mohamed Ksibi. The aim of her research work is to develop a novel and simple design of a sensors based on the modified carbon paste electrode for the detection of EDCs and to study the practical application of this sensors in real water samples.

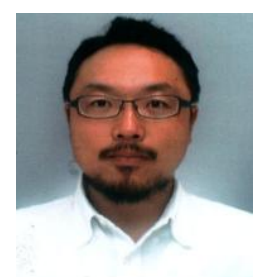

Mitsuteru Irie is an associate professor in environmental hydraulics at Faculty of Life and Environmental Sciences, University of Tsukuba, Japan.

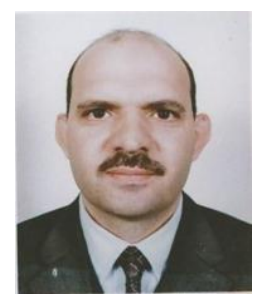

Mohamed Ksibi is a full professor in environmental chemistry at the University of Sfax (Tunisia). He is an author/co-author of about 54 papers in international scientific journals. His research interests are related to chemicals in the environment, water and wastewater treatment and reuse: the overlying goal of my research is the development and application of new methods for the identification of emerging chemical compounds in waters and wastewaters, the assessment of their toxicity and the development of new methods (advanced oxidation processes) for the degradation and removal of recalcitrant compounds. 